\title{
Using Body Language to Make and Maintain a Solid First Impression and to Decode Students' Behaviours
}

\author{
Özlem KÖPRÜLÜ*
}

\begin{abstract}
In daily life people use their body language subconciously and effectively. Some research findings have suggested that two thirds of communication and at least $75 \%$ of all classroom communication is nonverbal. Therefore, body language makes a great difference in helping teachers to make and maintain a solid first impression in a classroom full of curious students. This study tries to explain various body movements, gestures and facial expressions that could help teachers to leave a good impression on students and to decode students' behaviours correctly and behave accordingly. In order to learn students' ideas about how various gestures and body language affect them in the lesson, a questionnaire including six pictures and multiple choice questions were conducted on 53 randomly chosen 3 rd class students who are attending English Language Teaching Department at Buca Faculty of Education at Dokuz Eylul University and results were used to help teachers.
\end{abstract}

Keywords: Body language, First impression, Teachers, Gestures.

\section{İyi Bir İlk İzlenim Oluşturmak, Korumak ve Öğrenci Davranışlarını Deşifre Etmek İçin Beden Dilinin Kullanımı}

Öz

Günlük hayatta insanlar beden dillerini farkında olmadan ve etkili bir şekilde kullanırlar. Bazı araştırma sonuçlarına göre genel iletişimin üçte ikisi ve sınıf içi iletişimin en az \%75i sözsüzdür. Bu nedenle beden dili, meraklı öğrencilerle dolu bir sınıfta öğretmenlerin iyi bir ilk izlenim oluşturmalarına ve bunu korumalarına yardımcı olur. Bu çalışma, öğretmenlerin iyi bir ilk izlenim oluşturabilmelerine, öğrencilerin davranışlarını doğru yorumlayabilmelerine ve ona göre davranmalarına yardımcı olabilecek çeşitli beden hareketlerini, jestleri ve yüz ifadelerini açıklamaya çalışmaktadır. Farklı jest ve beden hareketlerinin öğrencileri derste nasıl etkilediğini öğrenmek için altı tane resim ve bunlarla ilgili çoktan seçmeli soruların olduğu bir anket Dokuz Eylül Üniversitesi Buca Eğitim Fakültesi İngilizce Öğretmenliği 3. sınıfa devam eden ve rastgele seçilen 53 öğrenciye uygulanmıştır ve sonuçlar öğretmenlere yardımcı olabilecek şekilde yorumlanmıştır.

Anahtar Kelimeler: Beden dili, İlk İzlenim, Öğretmenler, Jestler.

* PhD, Dokuz Eylül Üniversitesi Buca Eğitim Fakültesi, İngilizce Öğretmenliği, okoprulu10@hotmail.com 


\section{INTRODUCTION}

"You never get a second chance to make a first impression." Will Rogers.

"The most important thing in communication is to hear what isn't being said."Peter F. Drucker.

"Of those who say nothing, few are silent." Thomas Neill.

In daily life people generally use body language subconsciously and quite effectively, and first impressions are made by nonverbal cues rather than verbal cues. According to some research nonverbal cues are four times more impressive than what we say(Goman, 2008: 204). Author Malcolm Gladwell states that people begin to form first impresssions within seconds of meeting somebody. During this short period people make judgements about many things such as one's character, intelligence, temperament and suitability as a friend, etc. These conclusions, though based on little information, form first impressions that seldom change (Miller; 2005: 1).

Once Mae West said, "I speak two languages; body language and English."Nonverbal communication is defined as communication without words and it includes overt behaviours such as facial expressions, eye contact, touching, intonation, gestures and tone of the voice, but it can also be less obvious such as posture, dress and spatial distance. People convey so much information nonverbally in their conversations through gestures, eye-contact and physical distance.

How important is nonverbal communication in our life? Some research findings have suggested that two thirds of our communication is nonverbal. Dr. Albert Mehrabian from California University claims that only $\% 7$ of a message is sent through words while $\% 93$ is sent thro- ugh facial expressions (\%55) and vocal intonation (\%38) (Goman, 2008: 21). Some other research suggests that at least \%75 of all classroom communication is nonverbal. Therefore, body language makes a great difference with any kind of first impression, such as teachers'first few days in a classroom full of wide-eyed and curious new students.

When you enter the classroom, have you ever wondered....

-What kind of impressions am I making as a teacher?

-Did my whole students understand what I said?

-Is the class frustrated, bored or interested?

The answers to these questions are right before teachers' eyes. The silent signals of nonverbal communication generally reveal underlying motives and emotions such as fear, joy, honesty, frustration, indesicion, etc. The way people sit, stand or look at others reveals more about their true intention than they may realize.

Research studies with fifth grade, high school and college students found that learners at all levels reacted more favourably to teachers who used nonverbal immediacy cues: eye-contact, affirmative head nodding, leaning forward and smiling. Increasing immediacy behaviours dramatically improves students' motivation, how much they like a class and their willingness to follow the teacher's command (Goman, 2008: 5-6).

Teachers should be aware of nonverbal behaviour in the classroom for three major reasons:

a-An awareness of nonverbal behaviour will allow them to become a better receiver of students' messages. 
b-They will become a better sender of signals that reinforce learning.

c-This mode of communication increases the degree of the perceived psyhological closeness between the teacher and students(Ritz and Stein:1).

The effective use of nonverbal cues helps in most classroom practices by;

-reducing unnecessary teacher talking time

-increasing learner participation

-building confidence

-reducing fear of silence

-maintaining warm and friendly classroom atmosphere (Darn, 2005: 4).

Harry Wong, the author of the book "The First Days of School", emphasizes the fact that the first impression matters. According to him, body language is certainly a main part in creating the most important judgements of a teacher by the students. "Every time you act, you validate who you are"(Wong:54 in Body Language, online).

Students generally judge about their teachers and get a positive or negative first impression about them by observing their body language and appearance. Nalini Ambady conducted a study that asked college students to rate professors' personality traits based on a 10- second video recording of their teaching. Findings indicated that these ratings were uncannily similar to those made by students who completed an entire semester with the same professors. The study demonstrated that exposure to short period of nonverbal behaviour communicates a lot of information about people (Miller, 2005: 7).

The proper use of gestures and facial expressions in the teaching process will greatly help teachers communicate what they would like to transmit to their students accurately and lively. It is important to be aware of the dominance of nonverbal messages. When there is a discrepancy between verbal and nonverbal messages, the nonverbal will win. Knowing this fact teachers should have a "to do list to make a solid first impression".Some body movements, gestures and facial expressions and less obvious nonverbal cues which are thought to be important in the classroom environment are those:

1-Posture: Don't hide your body behind the desk, let your students see your whole body. In order to give positive nonverbal messages to students teachers should:

-stand "center stage" when they want everyone's attention, especially at the beginning of a lesson-this is a powerful signal that it is your show and you are ready to start.

-teachers should make sure that the students can see as well as hear them. They should not slouch in their chair and try to deliver a lecture.

-they should move around the room frequently -this tells the students that the teacher owns all the classroom space, which keeps the students' attention alive(http://www.classroom management-success.org/nonverbal-cues.htm)

A body posture gives signals about someone's interest in something, their openess and attentiveness. For example; if students slump in their chairs or over their desks, this often indicates boredom and discouragement. While they are attentive, they will sit up straight and lean slightly towards the teacher Teachers should also look for signals of discomfort such as rocking, leg swinging or tapping. When a students taps his finger on the desk, it means $s /$ he is either nervous or impatient.

However, when teachers deliberately want to control the class and want to give an authority feeling, they can do this by standing behind the 
table, lessening their body movements and gestures and having limited eye-contact.

2-Smile: It gives the message that the teacher is sincere and approachable. Teachers should smile while working with students as a smile is a warm and open invitation for communication. Witholding a smile can communicate to students that some of their behaviours hasn't gotten approval and is often more effective than words and it is the most powerful facial expression. Teachers who smile send out the message that:

-they are enjoying being with the students

-they are relaxed and confident.

Emotions are contagious. Swedish researchers revealed that just seeing a happy face gives the muscles an immediate stir that causes a smile (Goman, 2008: 83). Human brain prefers happy faces, and a smile is a very important part of having a good relationship.

3-Eye-contact: Looking straight into students' eyes forms a bond which creates a positive relationship between the teacher and students. It gives the feeling that one is open-hearted to another. Teachers should especially maintain eye-contact when they want to emphasize important points. Direct teacher eye-contact can express support, disapproval or neutrality. Experienced teachers often look at their students' eyes to gain their attention, judge their level of interest and to see how well they have understood the materials being taught. However, the teacher should not focus on a particular student or student group but make sure that they look around the classroom.

In Zeki Canan's research, four students reported that teachers' eye-contact can display their confidence or lack of confidence (Zeki, 2009: 1447). A teacher who never looks at students' eyes seem to lack confidence and gives the students a sense of insecurity(Gower and Wal- ters, 1993) and as a result, the teacher is likely to have some discipline problems.

In Zeki Canan's research, students' perception regarding the meaning of eye-contact was also examined. According to 15 students, eyecontact is a source of motivation and concentration for them(2009: 1446). Students also reported that eye-contact makes them feel important and confident which is in line with Ergin and Birol's (2005) views that if a person maintains eye-contact with you, it could be interpreted as that person cares for you or is interested in you which makes you feel important.10 students reported that they perceive eye-contact as a source of maintaining attention (2009: 1446). 8 students reported that their teacher's eyecontact helps them understand the topic better(2009: 1448). 6 students said that the teacher uses eye-contact while stressing something important about the course (2009: 1447).

Research shows that there is a strong link between the amount of eye-contact people receive and their degree of participation in communication (Zeki, 2009: 1447). Teachers should avoid rolling their eyes when they disapprove or are frustrated by a student because this is a powerful negative nonverbal cue that is dismissive of the student and counterproductive (http:www.classroommanagementsuccess.org/nonverbal-cues.html). If a student doesn't make an eye-contact and looks around the classroom, it could be assumed that $s /$ he isn't interested in the lesson.

4-Humour: Humour is often overlooked as a teaching tool but laughter releases tension in the classroom. Teachers should learn to laugh at themselves and encourage students to do the same because it fosters a friendly and warm atmosphere that facilitates learning.

5-Paralinguistic: Paralinguistic, which is the vocal intonation that includes rhythm, pitch 
and the tone of the voice, is very important in the classroom. Teachers should use a variety of vocal intonation while presenting a new material. Students have reported that they learn less and lose their interest more quickly while listening to teachers who have not modulated their voices (Ritts and Stein, y.y.: 3).

6-Dress: Being in a proper dress is an expression of respect to other people. According to some research people are more willing to help or to give information to people who are welldressed(Goman, 2008: 220). When the results of this research are taken into account, it could be concluded that teachers should be careful about how they dress on the first day of the school and during the time when they are at school.

7-Gestures: If used properly gestures can make teachers seem enthusiastic and committed to their topic; however, using too many gestures can make teachers appear nervous and uncontrolled. While speaking people use their hand movements unconsciously. Thanks to brain scanning techniques it has been observed that Broca area is active not only while speaking but also while using hand movements. In an experiment conducted with 100 children and adults researchers have found that using hand movements while explaining how they solved a math problem helped them remember more easily the lists of numbers they had learned before. When they were told not to use hand movements, they couldn't remember anything (Goman, 2008: 105).

Research has revealed that people have more positive feelings towards people who use their hand movements. According to research people who used their hand movements while communicating were accounted "sincere, energetic and amusing", whereas others who didn't were considered "logical, cold and analytical"(Goman,2008:106).

This study tries to explain the effects of a range of nonverbal cues such as body movements, gestures and facial expressions on students and how this information could be used to help teachers to leave a good impression on students and maintain it, and help them to decode students' behaviours correctly and behave accordingly.

\section{METHOD}

In order to learn students' ideas about how various gestures and body language affect them in the lesson, a questionnaire including six pictures and multiple choice questions was conducted on 53 randomly chosen 3rd class students who are attending English Language Teaching Department at Buca Faculty of Education at Dokuz Eylul University.

Pictures 1, 2, 3, 5, 6, 7 and 8 were used and students were allowed to choose more than one option about how the body language and gesture in the pictures made them feel.

\section{RESULTS}

According to the results of the questionnaire 42 students said that when they see their teacher as in Picture 1, it implies that s/he has some negative feelings and ideas about the students, and 19 of them reported that $s /$ he is bored with the lesson, and 6 of them said that s/he is open to new ideas.

According to some research if people fold their arms as in Picture 1,it indicates they not only have some negative feelings about the speaker but also they are not so interested in the topic.As it is seen, the reports are in accordance with the results of other research. 


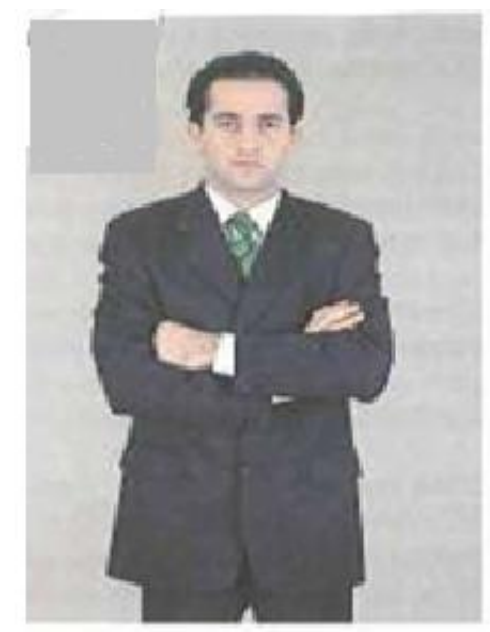

Picture 1

In an experiment volunteer groups were asked to attend a lesson. First group was told to sit in a relaxed position without folding their arms and crossing their legs. The second group was told to fold their arms closely on their chest. Results have shown that the second group learned \%38 less than the first group and remembered the things they learned less (Goman, 2008: 125).

If teachers encounter such students, what should be done? They should ask students to do something to change their posture; for instance, teachers can ask students questions to make them raise their hands or they can form groups to talk about a given topic. As long as it makes students unfold their arms, teachers can use any method that works. At the end of the lesson if teachers ask students questions with their arms folded on their chests, it is not surprising that there are no questions (Goman, 2008: 125).Research reveals that when people lean toward listeners, they get more verbal cues from their listeners (Goman, 2008: 36).Therefore; when teachers want to get answers from their students or to encourage them, they should lean forward slightly.

About Picture 2, 51 students said that when their teacher uses the gesture in Picture 2, it shows her/his self-confidence and comfort about her/his topic. Only 2 students said that it shows lack of confidence, and only 1 student said that it shows hostility.

When people have self-confidence or speak about a topic they know well, the most common hand movement is "tower gestu$\mathrm{re}^{\prime \prime}$ (Picture 2). This gesture is an expression of comfort and self-confidence. If teachers use it while teaching, this shows that they are selfconfident and are masters of their subjects. Our students' answers are in accordance with the explanation of the gesture.

When they see the gesture in Picture 3, 50 students reported that they feel threatened and show resistence to their teacher when $\mathrm{s} /$ he uses it, and only 4 said that they feel accepted.

The gesture in picture 3 is often used while accusing someone and mostly used by people who represent authority such as police officers and managers. However; such an authoritarian gesture is generally met with resistance and people are inclined to do the opposite. Therefore, teachers must be careful while using this kind of gesture in the classroom if they do not want to get resistance and hostility from their 
students. As it is seen, students' answers are

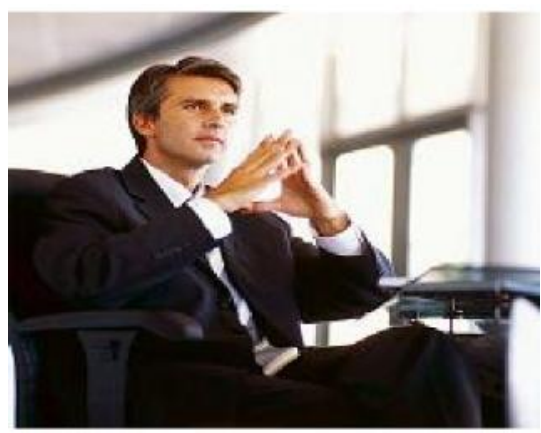

Picture 2.

Folding hands at the back also represents authority (Picture 4). Since people who fold their hands at the back expose all their weak parts such as chest and abdomen, they feel very powerful and self-confident and it shows absolute superiority. Thus teachers should use it when they want to impose discipline on students.

When we look at picture 5 ,we see that when students see their teacher as in picture 5, 53 students think that $\mathrm{s} /$ he is ready to accept new

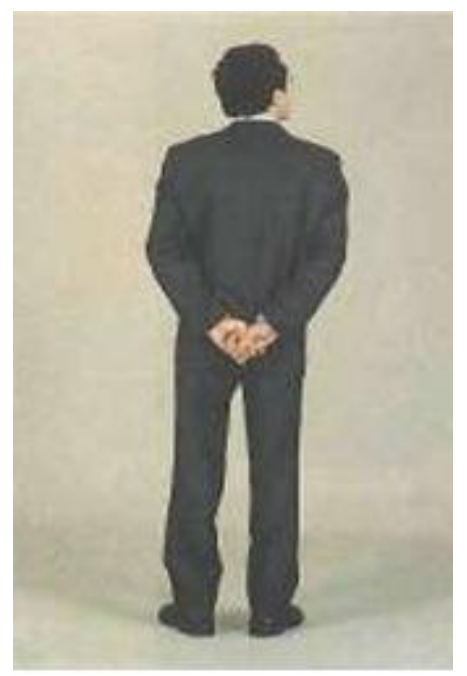

Picture 4.

Reciprocal behavioral expression, which is a communication technique imitating the body movements and posture of the interlocutor consistent with the meaning of this gesture.

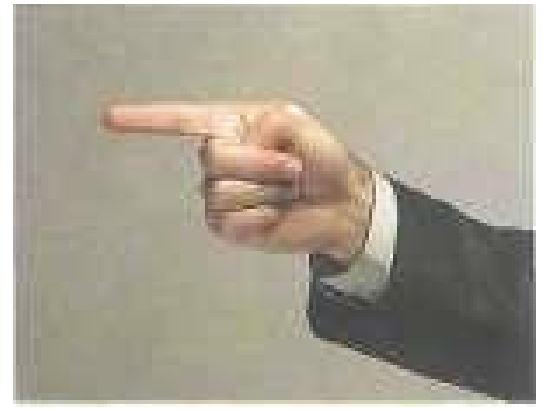

Picture 3.

and opposite ideas, and only 1 student said that $\mathrm{s} /$ he is not interested in the students.

People who expressed their ideas by using an open -hand gesture, as in picture 5 tell other people that they are ready to accept opposite ideas and they generally face with less resistance. So, teachers should use this gesture while teaching and asking questions as it also suggests equality, and students' answers comply with the implication of this gesture.

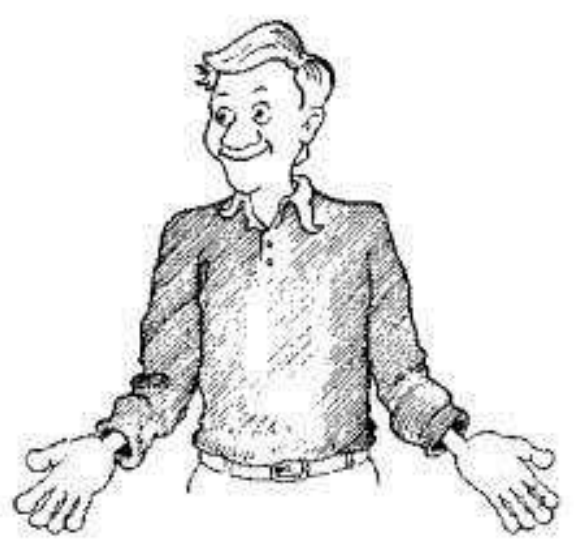

Picture 5.

subconsciously, is a very strong way of having good relationships. In some research two teachers were observed in the classroom. While one 
was using reciprocal expression, the other did not. The reaction of students toward the first teacher was more positive. They thought that this teacher was more successful, friendly and attractive (Goman, 2008: 47).

Being a good listener is one of the most important factors to make a solid first impression. If teachers give a short summary of the students' answers, students feel relaxed because when people hear what they said from the other person, they feel that they have been understood.

As for picture 6, 15 students said that their teacher is interested in what they say, 32 of them reported that the teacher is bored with what they say and 13 said that $\mathrm{s} / \mathrm{he}$ has some negative ideas about the student who is speaking at that moment. Here there is an interesting result. According to the explanation of this gesture, when people use this gesture, it means that they show interest in what the other person says. However, when we look at picture 9, we realize that the gestures in picture 6 and 9 are similar and most of the students must have interpreted the gesture in picture 6 like the one in picture 9 .

People who are interested in the topic they are listening to generally put their hands closed at their cheeks with their index -finger showing upward (Picture 6). Likewise, leaning the head at one side shows interest (Picture 7). While a teacher is explaining a topic if students make any of these gestures, the teacher can understand that the lesson is interesting for them. However; if they put their palms against their heads, this means that they have lost interest and begun to get bored (Picture 8). In this case it is a good idea to ask a few questions or do something else to renew their int

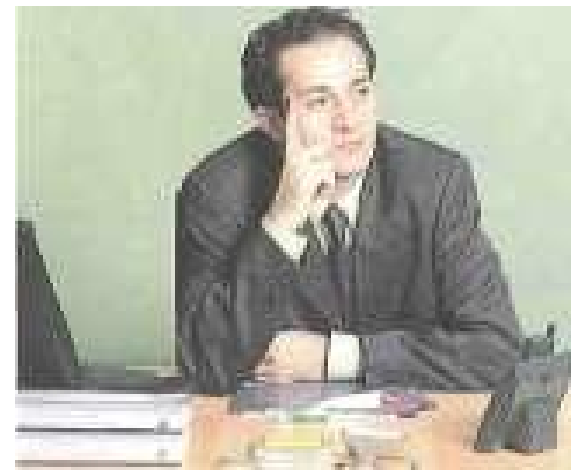

Picture 6.

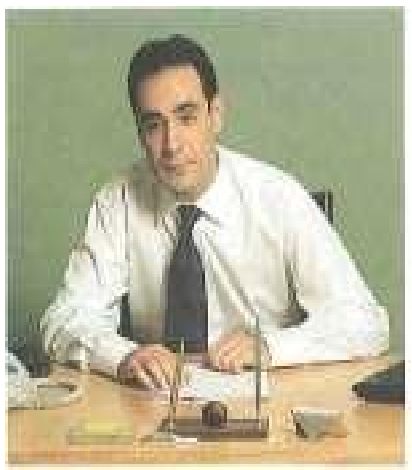

Picture 7.

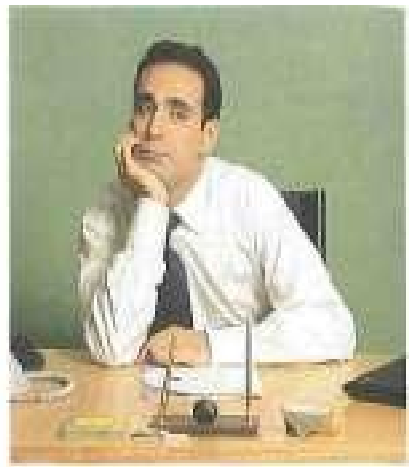

Picture 8.

Lastly, about pictures 7 and 8 in the questionnaire it was asked which picture shows interest and which one boredom.52 students said that picture 7 shows interest and picture 8 bore-

dom,which is again in line with the meaning of these gestures.Only 1 student said the vice versa. 


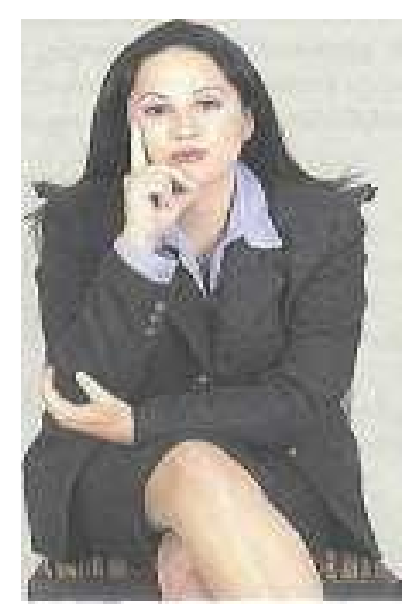

Picture 9.

If students sit as in picture 9, this shows that they have some negative ideas about the teacher or the topic s/he is talking about because in this critical listening arms and legs are used as hindrance. When teachers notice this gesture, they should ask students to write something to make them change the gesture. If students put their hands at their chins, this shows that they are coming to a decision. If this gesture is followed by folding arms and leaning back, the decision is negative. When teachers encounter such a gesture, it may be helpful to summarize main parts. If holding the chin is followed by leaning forward and sitting at the edge of their chairs, it could be seen as a sign that the topic has been welcomed by students (Baltas, 2002: 82).

During the lesson if students nod their heads slowly, this also means that they are interested in the topic (Goman, 2008: 100). If there are some students who close their mouths with their hands, it tells that they have some doubts about what the teacher is saying. When teachers notice these kind of things, they can say "I know some of you have some doubts about the thing I have just explained. May I learn what your anxieties are?" (Goman, 2008: 111).

\section{DISCUSSION}

This study attempted to investigate the effects of a range of nonverbal cues such as body movements, gestures and facial expressions on students by conducting a questionnaire with them and how this information could be used to help teachers to leave a good impression on students and maintain it, and help them to decode students' behaviours correctly and behave accordingly. A questionnaire including six pictures and multiple choice questions was conducted on 53 randomly chosen 3rd class students who are attending English Language Teaching Department at Buca Faculty of Education at Dokuz Eylul University.

Pictures 1, 2, 3, 5, 6, 7 and 8 were used and students were allowed to choose more than one option about how the body language and gesture in the pictures made them feel. According to the results of the questionnaire 42 students said that when they see their teacher as in Picture 1 , it implies that $\mathrm{s} /$ he has some negative feelings and ideas about the students. About Picture 2, 51 students said that when their teacher uses the gesture in Picture 2, it shows her/his self-confidence and comfort about her/his topic. As for picture 3, 50 students reported that they feel threatened and show resistence to their teacher when s/he uses it. For picture 5, when students see their teacher as in 
picture 5,53 of them think that $\mathrm{s} /$ he is ready to accept new and opposite ideas. Finally, about pictures 7 and 8 in the questionnaire it was asked which picture shows interest and which one boredom.52 students said that picture 7 shows interest and picture 8 boredom, which is again in line with the meaning of these gestures.

It is important for teachers to learn how to use hand and body movements while teaching in the classroom because they can support or reject the verbal messages they are giving. Students get nonverbal messages of enthusiasm and boredom through their teachers' body movements, and teachers can understand whether students are interested in the lesson or not through their body postures. Good teachers are good listeners, listening not only the words students say but also the nonverbal messages students send.

\section{CONCLUSION}

As a result, teachers should learn how to control and read nonverbal cues and use them to reinforce their verbal messages, which results in getting greater interest from students. A teacher could say many things to their students without saying a word. The response teachers get depends on the reaction they give. Listen to your students, show that you understand them, have eye-contact and smile, and then you will see that students have a positive and friendly attitude towards you. If teachers are not aware of their body language and cannot use it appropriately, their lessons would not be appreciated by their students. Moreover, students would not remember the teacher and the lesson. When teachers learn how to use their body language to make and maintain a solid first impression and to decode students' body language in the classroom, it will greatly help them communicate what they would like to transmit to their students accurately and lively, and they will have a long-lived happiness as teachers. "You are your attitudes" (Baltas, 2002: 166).

\section{References}

Baltas, Z. \& Baltas, A. (2002). Bedenin Dili. İstanbul: Remzi Kitabevi.

Body Language. Available on http://wik.ed.uiuc.edu/index.phb/Body_language.

Zeki, C. P. (2009). The Importance of Nonverbal Communication in Classroom Management. ProcediaSocial and Behavioral Sciences, 1(1), $1443-1449$.

Darn, S. (2005). Aspects of Nonverbal Communication. Internet TESL Journal, 11(2). Available on http://www.stevedarn.com.

Goman, C. K. (2008). İsyerinde Beden Dili. İstanbul: Melisa Matbaacılık.

Miller, W. P. (2005). Body Language in the Classroom (online). Available on www.acteonline.org.

Miller,W. P. (2006). Body Language on the Job (online). Available on www.amazon.com.

Nonverbal Cues: Learn How to Use Them Effectively in Teacher Student Communication(online). Available on http://www.classroom-management-success.org/non-verbal-cues.html.

Reca, Ö. F. (2010). Beden Dili ve Konuşma Sanatı. Ankara: Tutku Yayınevi. 
Ritts, V. \& Stein, R. J. (y.y.). Six Ways to Improve Your Nonverbal Communication(online). Available on http://stbweb02.stb.sun.ac.za/tutors/documents/SIX\%20WAYS\%20TO\%20IMPROVE\%20YOUR\% 20NONVERBAL\%20COMMUNICATIONS.pdf

Sunwani, V. K. (2009). Body Language and English Language Teaching(online). Available on http://www.zoominfo.com/CachedPage/?archive id=0\&page $i d=-$

1461171380\&page_url=//www.healingmatrix.ca/cgi-bin/move/mt-

view.cgi/2/entry/315/print entry\&page last updated=2010-11-

04T02:38:10\&firstName=Vijay\&lastName=Sunwani

www.smartclassroommanagement.com

www.hobicoffee.com

Zhu, A. (2006). The Importance of Using Body Language in English Teaching. US-China Foreign Language, 4(1), 79-81. 


\section{Genişletilmiş Özet}

Günlük hayatta insanlar beden dillerini farkında olmadan ve etkili bir şekilde kullanırlar. Bazı araştırma sonuçlarına göre genel iletişimin üçte ikisi ve sınıf içi iletişimin en az \%75 i sözsüzdür. Peter F. Drucker'ın dediği gibi, "İletişimde en önemli şey söylenmeyeni duymaktır." ve Mae West de söyle demiştir, "İki dil konuşuyorum: beden dili ve İngilizce." Sözsüz iletişim kelimeler kullanılmadan yapılan iletişim olarak tanımlanır ve yüz ifadeleri, göz teması, dokunma, tonlama, jestler ve ses tonu gibi açıç̧a görülen hareketleri içerdiği gibi daha az bariz olan vücut duruşu, kılık kıyafet ve uzamsal uzaklığı da içerir. Kaliforniya Üniversitesinden Dr. Albert Mehrabian iletişimin sadece \%7 sinin kelimelerle olduğunu, geri kalan \%93 ünün mimikler (\%55) ve tonlamayla (\%38) sağlandığını iddia etmektedir (Goman, 2008: 21). Bundan dolayı beden dili herhangi bir ilk izlenimde büyük bir öneme sahiptir, tıpkı öğretmenlerin meraklı gözlerle kendilerini bekleyen öğrencilerle dolu bir sınıftaki ilk birkaç günleri gibi. Will Rogers'ın söylediği gibi, “ Illk izlenimi oluşturmak için asla ikinci bir sansınız olmaz.”

Öğretmenler üç önemli nedenden dolayı sınıftaki sözsüz davranışların farkında olmalıdırlar:

a) Sözsüz davranışların farkında olmak öğrencilerden gelen mesajları daha doğru yorumlamalarına yardım eder.

b) Öğrenmeyi pekiştiren işaretleri daha etkili bir şekilde gönderirler.

c) Bu tür bir iletişim öğretmen ve öğrenci arasında algılanan psikolojik yakınlık düzeyini arttırır (Ritz and Stein).

Birçok sınıf uygulamasında sözsüz ipuçlarının etkili kullanımı,

- Gereksiz öğretmen konuşma zamanını azaltarak

- Öğrenci katılımını arttırarak

- Güven oluşturarak

- Sessiz kalma korkusunu azaltarak

- Sicak ve arkadaşça bir sınıf atmosferi yaratarak yardımcı olur (Darn, 2005: 4).

Sınıf ortamında önemli olduğu düşünülen bazı beden hareketleri, jestler ve mimikler ve daha az bariz sözsüz ipuçları şunlardır:

1-duruş 2-gülümseme 3-göz teması 4-espri 5-mimikler ve jestler 6-ses tonu 7- k1lık kıyafet

Bu çalışma beden dili, jestler ve mimikler gibi bir dizi sözsüz ifadenin öğrenciler üzerindeki etkisini açıklamaya çalışmaktadır ve ayrıca öğretmenlerin iyi bir ilk izlenim oluşturmalarına ve devam ettirmelerine yardımcı olmak ve öğrencilerin davranışlarını doğru yorumlayıp ona göre davranmalarında yol göstermeyi amaçlamaktadır.

Farklı jest ve mimiklerin ve beden dilinin öğrencileri derste nasıl etkilediğini öğrenmek için altı resim ve bunlarla ilgili çoktan seçmeli soruların olduğu bir anket Dokuz Eylül Üniversitesi Buca Eğitim Fakültesi İngilizce Öğretmenliği 3. Sınıfa devam eden ve rastgele seçilen 53 öğrenciye uygulanmıştır. 1.2.3.5.6.7 ve 8. resimler kullanılmıştır ve öğrenciler resimdeki beden dili ve jestin onlara nasıl hissettirdiği ile ilgili seçenekleri işaretlemişlerdir.

Anket sonuçlarına göre 42 öğrenci öğretmenlerini resim 1'deki gibi gördüklerinde, onun öğrenciler hakkında birtakım olumsuz duygu ve düşünceye sahip olduğunu ima ettiğini söylemişlerdir. Öğretmenleri resim 2' deki gibi bir jest yaptığında 51 öğrenci bunun öğretmenin konusuna hâkim olduğunu ve kendine güvendiğini gösterdiğini söylemistir.50 öğrenci de öğretmenleri resim 3'deki jesti yaptığında tehdit edilmiş hissettiğini ve yüzden direnç gösterdiğini rapor etmiştir. Öğretmenlerini resim 5'teki gibi gördüklerinde 53 öğrenci onların yeni ve karşıt fikirleri kabul etmeye hazır olduklarını düşündüklerini 
belirtmiştir. Son olarak ta,7. ve 8. resimlerden hangisinin ilgiyi, hangisinin sıkıntıyı gösterdiği sorulduğunda 52 öğrenci 7. resmin ilgiyi, 8. resmin sıkıntıyı gösterdiğini belirtti ki bu sonuç resimlerdeki jestlerin anlamları ile uyum içindedir.

Sonuç olarak öğretmenler sözsüz ipuçlarını nasıl yorumlayıp kontrol edeceklerini öğrenmeli ve bunları sözlü mesajları pekiştirmek için kullanmalıdırlar ki bu şekilde öğrencilerin daha fazla ilgisini çekebilirler. Bir öğretmen tek kelime etmeden öğrencilere pek çok şey söyleyebilir. Öğretmenler beden dilini iyi bir ilk izlenim oluşturmak ve korumak ve öğrenci davranışlarını doğru yorumlamak için nasıl kullanacaklarını öğrendiklerinde, bu durum onlara öğrencilere iletmek istediklerini doğru ve dinamik bir şekilde iletmelerine büyük ölçüde yardımcı olacaktır. 